\title{
Studying key users' skills of ERP system through a comprehensive skill measurement model
}

\author{
Maryam Mahdavian • Fahimeh Mostajeran
}

Received: 20 February 2012 / Accepted: 18 June 2013 / Published online: 20 July 2013

(C) The Author(s) 2013. This article is published with open access at Springerlink.com

\begin{abstract}
Given to the significant role of enterprise resource planning systems (ERP) in the current organizations, several studies have been accomplished regarding these systems. The Main reason for the present research is having a small share in enhancement of success rate of ERP systems implementation through an applied study. In this study two purposes are pursued. First, this article intends to determine the most important skills required by key users (Also called power users and super users.) of ERP system as one of the most major members of ERP implementation team. Another purpose is to examine the skills shortages of these users in organizations under study and both of these purposes are obtained based on a comprehensive model. This research includes two major parts. First, based on experts' opinion, a model is developed to determine and measure required technical, human, and conceptual skills as well as skills shortages of those involved in ERP implementation such as key users. Then, in second part, based on the above model and by means of a field study and studying thirteen Iranian organizations, the desirable amount (Amount of skill that key users expected to have.) and existing amount (Amount of skill that key users have at present.) of skills of key users are measured in each one of the technical, human, and conceptual categories. Then in order to determine and evaluate skill shortages, the difference between these two amounts in each category is examined. In this paper, human and conceptual skills are determined as the most important skills of key users in ERP implementation. Also, results confirm that key users have skills shortages in three kinds of main skills (i.e., technical, human, and conceptual) in the organizations under study. Moreover,
\end{abstract}

M. Mahdavian $(\bowtie)$

Department of Computer, Meymeh Branch, Islamic Azad

University, Meymeh, Iran

e-mail: mahdavian.maryam@iaumeymeh.ac.ir

F. Mostajeran

Young Researchers and Elite Club, Meymeh Branch,

Islamic Azad University, Meymeh, Iran key users in large companies suffer more from skills shortages than ones in SMEs.

Keywords Enterprise resource planning system $\cdot$ Human skills $\cdot$ Technical skills $\cdot$ Conceptual skills $\cdot$ Skills shortages · Key users

\section{Introduction}

Due to intense market competition and the progress of information technology (IT), many companies have implemented enterprise resource planning (ERP) systems to enhance their competitiveness [1]. In general, the literature has identified the following potential benefits of ERP systems implementation [2]: improved coordination across functional departments, increased efficiency in doing business, reduced operating costs, facilitation of day-to-day management, rapid access to information for decision making and managerial control, and support of strategic planning.

Despite the attributes and major advantages provided by ERP systems, the implementation of such systems is not always effective [2] and there is a high rate of failure in implementation of these systems [3-5]. Foe examples companies such as Fox-Meyer Drug, Mobile Europe, Dell, Whirlpool, Hershey, Whirlpool, Hershey Foods, Boeing, Applied Materials, Kelloggs, and Nestle are cited in literature which have either failed in ERP systems implementation or suffered from ineffective ERP systems [6, 7].

Therefore, during recent years, in order to improve the chances of success of ERP implementation, researchers have performed valuable efforts and some of them have attempted to identify the set of effective factors in ERP implementation. Many of these authors have introduced a list of critical success factors and some of them a list of risks and failure factors. Among these CSFs lists, project team competence and good project team are cited frequently [4, 8-11]. Also, 
some researchers have stated poor project team skills as a risk and failure factor of ERP systems [5, 12-15].

As a result, in ERP literatures, the importance of team competence and selection of the right team members with proper knowledge and skills have mostly been pointed. The success of any project depends critically on its team members. Specially, an ERP project requires a cross-functional and multi-skilled implementation team because of its enterprisewide scope [16]. It brings a need to ensure that team members have the requisite skills. Moreover, since ERP systems are more complicated than any traditional information system [1], identifying and evaluating skills needs of those individuals who are dealing with this system seems more critical.

The present study makes two contributions to the ERP implementation literature:

(1) Paying more attention to the competency and skills of those individuals who play a role in ERP implementation and providing a model for measuring the requisite skills as well as skills shortages of them.

(2) Studying the skills of key users of ERP to identify the most important skills required by them and evaluate skills shortages of these users.

This paper has been organized as below:

Reviewing some literature related to team competency as one of the effective factors in ERP implementation, skills shortages, the important role of key users in implementation of ERP system, and skill measurement model developed in this study to determine and measure required technical, human, and conceptual skills of those individuals involved in ERP implementation project such as key users are stated in next section. Section 3 mentions the research methodology and hypotheses. Results obtained from statistical data analysis are shown in section 4. Section 5 represents the discussion about the research results. Practical implications and research limitations are illustrated in sections 6 and 7, respectively. Eventually conclusion along with a summary of main findings is stated as last section.

\section{Related literature}

\subsection{Team competency as an effective factor}

"A team is a small number of people with complementary skills who are committed to a common purpose, performance goals, and working approach for which they hold themselves accountable" [17]. Benders [18] describes the concept of teams as including technical, social, and organizational skills. Katzenbach and Smith [17] state:

No team succeeds without all the skills needed to meet its purpose and performance goals. Yet most teams figure out the skills they will need after they are formed. The wise manager will choose people both for their existing skills and their potential to improve existing skills and learn new ones ([17]; pp. 62, 137).

Although, enterprise resource planning systems that according to Davenport [3] "are the most important development in corporate use of information technology in the 1990s" have enhanced productivity of many organizations, there are other organizations that have been failed in this regard and could not have used these systems properly. Thus, today various scientific articles have been represented to explain effective factors on successful implementation of these systems. Although there is no general consensus on the critical success factors of an ERP implementation [10], many researchers have considered the competencies and abilities of project team as one of the most important CSFs. Somers and Nelson [8] identified the most critical factors in implementation of enterprise resource planning systems in their study. They specified 22 critical factors in successful ERP implementation based on an extensive study in literature and then importance of these factors, during implementation phases, were ranked by senior managers of information systems of companies which had been selected from the "Fortune 500 List." Team competency was ranked as the second critical factor in ERP implementation after senior managers' support factor in this survey. Piotr Soja [9] identified critical success factors in his research and team composition, which states the implementation team includes different individuals who have high competency and knowledge, was determined as the third effective factor on successful implementation based on the obtained results. Many other authors have referred to the importance of competency, capability, and skills of the project team in ERP implementation too [19-23].

On the other hand, many accomplished researches in the field of enterprise resource planning systems have identified the existing risks and dangers in ERP implementation projects. One of the most important researches has been conducted by Sumner [12]. She studied seven implementation projects of enterprise-wide information management system and identified 20 risk factors through a structured interview with project managers of companies and organized these factors into six categories. One of these categories is skill mix including: insufficient training and re-skilling, insufficient internal expertise, lack of business analysts with business and technology knowledge, failure to mix internal and external expertise effectively, and lack of ability to recruit and retain qualified ERP systems developers. In another research that was conducted by Aloini et al. [14], risk factors were identified based on a literature review and analyzing key articles in the field of ERP implementation and as a result poor project team skills was determined as one 
of top 10 risk factors. Hawari and Heeks [15] investigated the degree of fit between the assumptions and requirements built into ERP system design and the actual realities of the client organizations. The findings of this study show that there is a sizeable gap between requirements and actual realities in 'staffing and skills' dimension stated as one of the most likely causes of ERP project failure in developing countries. Kumar [13] in his study asked respondents to identify major obstacles that they faced in the ERP implementation project and as a result, unavailability of skilled people came up as the second major barrier.

\subsection{Skill shortages}

Although there are many definitions of a skill shortage, the general consensus and simplest definition is "when there are not enough people available with the skills needed to do the jobs which need to be done" [24]. Some major reasons which can affect skills shortages are as follows: growth in the economy, structural changes, organizational changes, technological change, the computer and Internet revolution, international competition and globalization, demographic changes, mega projects, and lack of training [25, 26]. Overall, there are two major types of skill/labor shortages: cyclical and structural. Factors that contribute to structural shortages can include significant demographic changes, technological changes, and rapid growth of new industries. Structural shortages are more difficult to address through market responses because the available labor pool may not have the skills needed and it can take considerable time to develop these skills [26]. There is a wide range of potential responses to tackle skills shortages: raising wages and/or fringe benefits or altering the working conditions, recruiting new workers even overseas recruitment, delaying retirement of older workers, education and training, and substituting labor and telecommuting [26, 27]. Most of the impacts of skills shortages, such as overtime and increasing costs, are negative for an organization's growth and productivity [28, 29]. Shortages in skilled staff cause disruptions to project schedules thereby causing the firm to work its existing employees to a greater extent [29].

\subsection{Technological change and skill shortages}

As mentioned above, technological change is one of the common sources of skills shortages. The relationship between technological change and human capital update or the adaptability of skills has received some attention from a theoretical point of view [30]. Haskel and Martin [31] in their study state that there is a link between skill shortages and technology. They ask this question in their paper "Why have skill shortages continue to persist despite increases in training and the skill levels of the workforce?" their answer for this persistence of skill shortages is the speed of technical change. They show that skill shortages are higher for establishments that use advanced technology.

It is obvious that implementation of new complicated technologies such as enterprise information systems is along with changes such as individual skills in organization. Implementation often requires changes in individual skills, cognitions, and expectations, as well as changes in formal roles and structures [32]. IT transfer is accompanied by the transfer of organizational structures routines and skills [33]. It seems clear that deep structural changes and reorganizing causes going through the trouble to clarify the skills needed in new positions [34].

The issue of skill shortage is more visible in developing countries. Developing countries are endeavoring to advance into the twenty first century information age. Their progress, however, is hamstrung by the dire lack of trained, skilled, and knowledgeable IS workers [35]. Nevertheless, skill shortages are currently widening across countries and industries [30]. The European Competitiveness Report 2001 [36] identifies a serious shortage of core ICT workers in Western Europe. Recent research from analysts, practitioners and employers within the IT industry has acknowledged that a skills gap is posing a threat to British business. While the number of job opportunities within the IT industry is gradually rising, employers are finding it increasingly difficult to track down the right candidate for advertised vacancies [37].

\subsection{Key users}

Given the above issues, more detailed and applied studying of competency of the project team members is necessary. Since key users are among the most important individuals in implementation projects of ERP, in this study, the focus is on these individuals. According to $\mathrm{Wu}$ and Wang [38] stakeholders who are taking part in the process of ERP implementation include the following cases: internal project team that defines needs of the organization and external contractor that represents a system according to needs of the organization. As it is shown in Fig. 1, internal project team includes top management, MIS staff, and key users (user representatives).

Given to Fig. 1, key users' role is important. They are the connection bridge between consultants and the organization as well as between end users and the project team. Key users are selected from operating departments and are generally familiar with business processes and having domain knowledge of their areas [38]. The findings of the study done by Maditinos et al. [2] state that knowledge transfer is an extremely significant factor for ERP system success. Key users play a significant role in knowledge transfer [39, 40]. In the initiation of a project, the implementation consultants possess ERP knowledge and key users business process knowledge. Effective implementation requires consultants to 


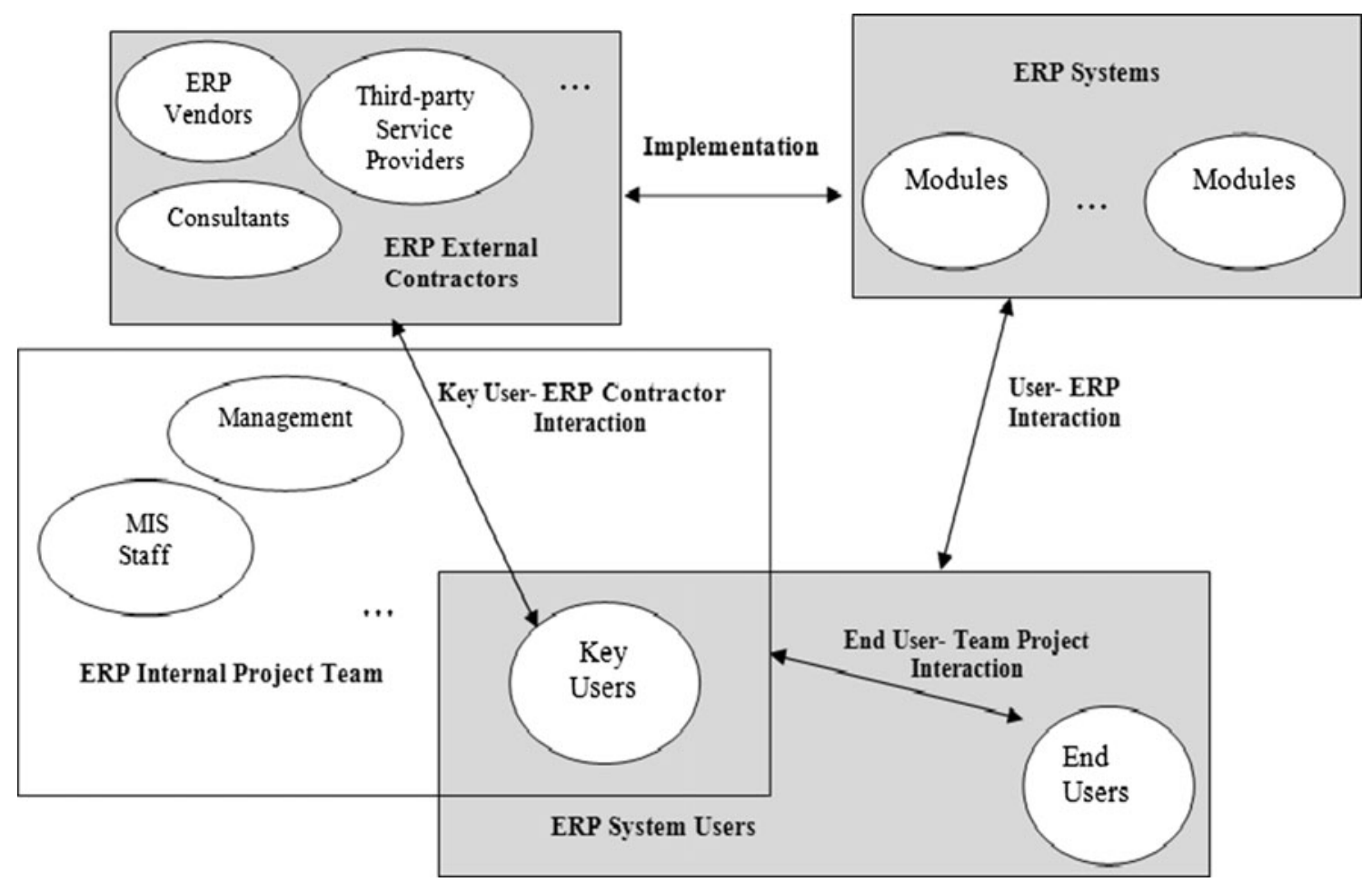

Fig. 1 The ERP implementation context [38]

absorb business process knowledge from key users and key users learn ERP knowledge from consultants [41]. Then based on what key users learn, they are responsible for training and sharing their knowledge with other users [38, 40, 42]. Key users are developers of the requirements for the ultimate system. They will specialize in parts of the ERP system and act as trainers, help-desk resources, educators, advisors, and change agents for end users [38]. Lo et al. [43] in their article state the job tasks at different stages of ERP system implementation in Application Implementation Methodology (AIM). The fact that key users are involved in almost all stages and have different tasks is noteworthy. Therefore key users' role is essential to the ultimate system's success [38]. After implementation, they return to their departments as resident ES experts [40].

\subsection{Skill measurement model}

Given to the role of key users which was mentioned above, they have to be qualified and skillful. Therefore in this research skills required by key users of ERP systems and their skills shortages in organizations under study have been studied. In this regard, creating a comprehensive model to determine and measure skills required by those involved in the project such as key users is essential. To develop this model, at first, major accomplished studies in the field of skills classification were studied. Table 1 summarizes classifications of skills presented by some authors.
Then, Katz model that is one of the most complete and valid models was applied as the basis model, since Katz categorization includes most of the other categorizations, and many other skills models have been built upon the technical, human, and conceptual skill classification, but are slightly different [57]. This model includes three main categories:

Technical skills, according to Katz [49], are the most concrete type of skills and are associated with understanding and being able to complete specific activities. In other words, these are the "how to do it" skills and involve methods, processes, procedures, or techniques.

Human skills can be considered the "people skills." Katz [49] defined human skills as "the ability to work effectively as a group member and to build cooperative effort within the team he leads." This skill is demonstrated in how a leader perceives and behaves towards those around him/her, including superiors, peers, and followers, and most importantly cannot be a "some-time skill," but rather must be demonstrated in every action of the leader [49].

Conceptual skills can be thought of as the "thinking skills" needed by leaders. This type of skill involves being able to see both what is going on within an entire organization, and how the various parts of the organization interact and depend on one another [49]. Yukl (2002, cited in Huusko [58]) supports Katz's classification of skills in these three categories and explains that conceptual skills are also called "cognitive" and refer to logical thinking, analytical abilities, inductive, and deductive reasoning. 
Table 1 Kindly check if the tables and its entries are correctly captured and presented. Summary of types of skills by authors

\begin{tabular}{|c|c|}
\hline Author(s) & Types of skills and models \\
\hline$[44]$ & Hard skills \\
\hline$[45]$ & Soft skills \\
\hline \multirow[t]{3}{*}[46]{} & Personal skills \\
\hline & Interpersonal skills \\
\hline & Group skills \\
\hline \multirow[t]{3}{*}{ [47] } & Hard skills \\
\hline & Portable skills \\
\hline & Soft skills \\
\hline \multirow[t]{2}{*}{ [48] } & Management skills \\
\hline & People skills \\
\hline \multirow[t]{3}{*}[17]{} & Technical skills \\
\hline & Decision-making skills \\
\hline & Interacting skills \\
\hline \multirow[t]{3}{*}[18]{} & Technical skills \\
\hline & Social skills \\
\hline & Organizational skills \\
\hline [49] & Technical skills \\
\hline \multirow[t]{2}{*}[50]{} & Human skills \\
\hline & Conceptual skills \\
\hline \multirow[t]{3}{*}[51]{} & Technical skills or functional expertise \\
\hline & Problem-solving and Decision-making skills \\
\hline & Interpersonal skills \\
\hline \multirow[t]{5}{*}[52]{} & Problem solving skills \\
\hline & Communication skills \\
\hline & Conflict resolution skills \\
\hline & Goal setting skills \\
\hline & Planning tasks skills \\
\hline \multirow[t]{4}{*}[53]{} & Technical expertise \\
\hline & Communication / Interpersonal \\
\hline & Problem identification / Solving \\
\hline & Conflict resolution / Negotiation \\
\hline$[54]$ & ICT skills \\
\hline \multirow[t]{3}{*}[55]{} & Purely technical skills \\
\hline & Cognitive abilities \\
\hline & Emotional intelligence \\
\hline \multirow[t]{4}{*}{ [56] } & Technical skills \\
\hline & Industry knowledge \\
\hline & Analytic and conceptual reasoning \\
\hline & Interpersonal and emotional intelligence \\
\hline \multirow[t]{6}{*}{ [57] } & Human Skills \\
\hline & Conceptual Skills \\
\hline & Technical Skills \\
\hline & Communication Skills \\
\hline & Emotional Intelligence Skills \\
\hline & Industry Knowledge Skills \\
\hline
\end{tabular}

After choosing Katz classification as the basis model, various articles regarding information systems, enterprise resource planning systems, IT, and managerial skills were studied to determine indices of each major category (i.e., technical, human, and conceptual) and finally 22 indices (skills) were considered. These indices have been illustrated in Table 2 along with a brief description of indices and references which have referred to these indices.

In sections 3 and 4 , it will be stated that each of the indices shown in Table 2 belongs more to which major category or categories of technical, human, and conceptual skills.

\section{Research methodology and hypotheses}

As mentioned earlier, this study includes two parts. In the first part we will explain development manner of the model to determine and measure technical, human, and conceptual skills required by those individuals involved in implementation of ERP system. In the second part, the desirable amount and existing amount of skills of key users are measured given to the developed model in the previous part and then skills shortage is studied in each category (technical, human, and conceptual). Therefore, methodology and hypotheses of each part will be stated in the following separately.

\subsection{Methodology and hypotheses of the first part}

The purpose of this part is to classify 22 indices shown in Table 2 to major categories of technical, human, and conceptual skills based on experts' opinion. The tool in this part was a questionnaire including 22 questions (see Appendix 1). Respondents consisted of proficient individuals including university professors, managers of organizations as well as experts of enterprise resource planning systems. They were asked to determine the place of each 22 indices in Table 2 in relation to main categories of technical, human, and conceptual skills. Thus, the following 22 hypotheses were proposed.

$$
\begin{aligned}
& \mathrm{H}_{0:} \mathrm{P}_{\mathrm{iT}}=\mathrm{P}_{\mathrm{iH}}=\mathrm{P}_{\mathrm{iC}} \quad \mathrm{i}=1,2, \ldots, 22 \\
& \mathrm{H}_{1} \quad: \quad \text { otherwise }
\end{aligned}
$$

$\mathrm{P}_{\mathrm{iT}}$ shows ratio of individuals who believe that index $\mathrm{i}$ is settled in the main category of technical skills.

$\mathrm{P}_{\mathrm{iH}}$ shows ratio of individuals who believe that index $\mathrm{i}$ is settled in the main category of human skills.

$\mathrm{P}_{\mathrm{iC}}$ shows ratio of individuals who believe that index $i$ is settled in the main category of conceptual skills.

Seventy questionnaires were collected in this part. The amount of Cronbach's alpha was obtained equal to 0.77 in order to evaluate reliability of the questionnaire and chisquare test was used to test hypotheses (a). 
Table 2 Indices, references, and description

\begin{tabular}{|c|c|c|c|}
\hline No. & Index & Author(s) & Description \\
\hline 1 & Change Management & {$[59],[60],[22],[20]$} & $\begin{array}{l}\text { Knowledge of change management principle and strategies, familiarity with ways in } \\
\text { order to encounter change resistance }\end{array}$ \\
\hline 2 & Stress Management & {$[61]$} & Identifying stress factors and finding strategies in order to face with stress \\
\hline 3 & $\begin{array}{l}\text { Technology Management } \\
\text { Knowledge }\end{array}$ & {$[62]$} & $\begin{array}{l}\text { Ability to learn new technologies, Ability to focus on technology as a device not an } \\
\text { object, Ability to understand technological trends }\end{array}$ \\
\hline 4 & Project management & $\begin{array}{l}\text { [63], [64], [22], [20], [65], } \\
{[66],[67],[13]}\end{array}$ & $\begin{array}{l}\text { Having knowledge and experiences about techniques, principle and tools of Project } \\
\text { management }\end{array}$ \\
\hline 5 & Information Literacy & {$[68]$} & $\begin{array}{l}\text { Recognition of information needs, evaluation, organization and effective utilization } \\
\text { of information }\end{array}$ \\
\hline 6 & $\begin{array}{l}\text { Negotiation and Conflict } \\
\text { Management }\end{array}$ & {$[69]$} & Negotiation and Discussion skill, mediation and Arbitration skill \\
\hline 7 & Risk Management & {$[60],[70]$} & Identification, evaluation, analysis, control and managing of the risk \\
\hline 8 & $\begin{array}{l}\text { Teaching and Training } \\
\text { Skills }\end{array}$ & {$[62],[63],[22],[64],[66]$} & $\begin{array}{l}\text { familiarity with teaching and training methods, Teaching evaluation methods, } \\
\text { Measuring the degree of User learning }\end{array}$ \\
\hline 9 & Crisis Management & {$[71],[72]$} & $\begin{array}{l}\text { familiarity with essential actions in every step of crisis management process (before } \\
\text { crisis, during crisis, after crisis) }\end{array}$ \\
\hline 10 & Organizing & {$[58],[73]$} & ability to coordinate and organize the elements within a system \\
\hline 11 & Leadership Skills & {$[74],[64],[71]$} & Being able to influence, motivate, and direct \\
\hline 12 & $\begin{array}{l}\text { ERP Technical } \\
\text { Knowledge }\end{array}$ & {$[62],[64],[67]$} & $\begin{array}{l}\text { ERP Administration, Networks, Knowledge of ERP concepts, Operating systems, } \\
\text { System Design/Integration, Systems' Life Cycle Management, Data Management }\end{array}$ \\
\hline 13 & General Skills & {$[75],[76],[77]$} & English language, computer skills \\
\hline 14 & $\begin{array}{l}\text { Business Processes } \\
\text { Knowledge }\end{array}$ & $\begin{array}{l}{[4],[62],[63],[65],[60]} \\
{[66],[22],[78],[64]}\end{array}$ & $\begin{array}{l}\text { Knowledge of business processes and relevant processes, Knowledge of Business } \\
\text { Functions, Ability to understand needs of customers quickly, Ability to understand } \\
\text { the business environment, Ability to interpret business problems, Ability to } \\
\text { develop appropriate technical solutions about business problems, proficiency in } \\
\text { business Process Reengineering, quick resolving of process bottlenecks }\end{array}$ \\
\hline 15 & Analytical Skills & {$[64]$} & Analytical thinking and Reasoning (Deductive and inductive) \\
\hline 16 & Team Skills & {$[62],[20]$} & $\begin{array}{l}\text { Ability to work cooperatively in a team environment, Understanding group dynamics, } \\
\text { Team management, Team building }\end{array}$ \\
\hline 17 & Personal Skills & [79], [71] & $\begin{array}{l}\text { Creative thinking; Critical thinking, Persistence; Curiosity; Risk-taking, Acceptance } \\
\text { of responsibility; trustworthiness, Flexibility; Adaptability, paying attention to } \\
\text { details, Memory, sensitivity towards organizational culture, positive attitude, } \\
\text { Tolerating uncertainty, Working independently, Self-esteem }\end{array}$ \\
\hline 18 & Strategic Planning & {$[74],[80],[81],[63]$} & $\begin{array}{l}\text { Integration of efforts to achieve mission and long term goals, Having Long term } \\
\text { vision, Recognizing opportunities, Goal setting, Prioritizing, Setting strategies, } \\
\text { tactics and policies, Allocation of resources }\end{array}$ \\
\hline 19 & System Skills & {$[82],[83],[84]$} & System thinking, Ability to consider the whole process and big picture \\
\hline 20 & Communication Skills & {$[63],[66],[22],[20]$} & $\begin{array}{l}\text { Ability to communicate effectively( Electronic communication, Verbal } \\
\text { communication, Written communication), Relationship builder, Relationship } \\
\text { management }\end{array}$ \\
\hline 21 & Time Management & [64], [85] & Familiarity with strategies and principle of time management and effective use of time \\
\hline 22 & $\begin{array}{l}\text { Decision Making and } \\
\text { Problem Solving Skills }\end{array}$ & [86], [87] & $\begin{array}{l}\text { Problem definition, determination of solutions, Evaluation of solutions, Selecting best } \\
\text { Solutions, evaluation of solution results. }\end{array}$ \\
\hline
\end{tabular}

It is noteworthy that in order to confirm the experts' opinion, factor analysis method was also used in this part.

\subsection{Methodology of the second part}

The research tool in the second part was a questionnaire including 44 questions. Twenty two questions studied desirable amount of each of the indices for key users and 22 questions studied existing amount of such indices for key users. These amounts were measured using range 1-10 (see Appendix 2). This study was conducted in 13 Iranian companies including steel, automobile, energy, tobacco, glass, electric home appliances, printing, chemical, mining, and thermal home appliances industries, 2 of which belong to large companies and eleven of which are SMEs. Respondents consisted of key users, project managers, ERP experts, and consultants of ERP implementation. 
To determine the survey sample size, a combination of stratified and two-stage cluster sampling methods considering 0.1 as the margin of error has been used. At first, the population was divided into large companies and SMEs. After that, 2 large companies and 11 SMEs were randomly selected at first stage of cluster sampling and then randomly 50 and 62 respondents were chosen from companies in each strata, respectively. Finally, 106 questionnaires were usable for research. Six of the returned responses were not included for such reasons as incomplete questionnaires, responses with too much missing data, and etc.

\subsection{Hypotheses of the second part}

In this part, it is studied that which of the main technical, human and conceptual skills is more important for key users in ERP implementation. This question is answered given to measurement of desirable amount of skills (the skill level that key users must have). Therefore the below hypothesis is proposed:

$\mathrm{H}_{0:} \mu_{\mathrm{DT}}=\mu_{\mathrm{DH}}=\mu_{\mathrm{DC}}$

$\mathrm{H}_{1}$ : otherwise

$\mu_{\mathrm{DT}}$ is the average desirable amount of technical skills.

$\mu_{\mathrm{DH}}$ is the average desirable amount of human skills.

$\mu_{\mathrm{DC}}$ is the average desirable amount of conceptual skills.

Desirable amount of technical skills is the average of desirable amount of indices that are settled in the technical skills category based on the results of hypotheses (a).

Desirable amount of human skills is the average of desirable amount of indices that are settled in the human skills category based on the results of hypotheses (a).

Desirable amount of conceptual skills is the average of desirable amount of indices that are settled in the conceptual skills category based on the results of hypotheses (a).

Repeated measures test (within-subjects effects test) was used to test hypothesis (b) given that respondents were similar in each of the three groups.

Another proposed question in this part is whether there is a difference between desirable amount and existing amount of skills of key users in each main category of technical, human, and conceptual skills which means whether there is skills shortage in each main category or not. Hence the following three hypotheses are proposed:

Hypothesis (c): H0: there is no difference between the average of desirable amount and the average of existing amount of key users' technical skills. (There is not technical skills shortage)

$\mathrm{H}_{1}$ : there is a difference between the average of desirable amount and the average of existing amount of key users' technical skills. (There is technical skills shortage)

$\mathrm{H}_{0:} \mu_{\mathrm{DT}}=\mu_{\mathrm{ET}}$

$\mathrm{H}_{1:} \mu_{\mathrm{DT}} \neq \mu_{\mathrm{ET}}$

$\mu_{\mathrm{ET}}$ is the average existing amount of technical skills.

Desirable amount of technical skills is the average of desirable amount of indices that are settled in the technical skills category based on the results of hypotheses (a).

Existing amount of technical skills is the average of existing amount of indices that are settled in the technical skills category based on the results of hypotheses (a).

Hypothesis (d): $\mathrm{H}_{0}$ : there is no difference between the average of desirable amount and the average of existing amount of key users' human skills. (There is not human skills shortage) $\mathrm{H}_{1}$ : there is difference between the average of desirable amount and the average of existing amount of key users' human skills. (There is human skills shortage)

$$
\begin{aligned}
& \mathrm{H}_{0:} \mu_{\mathrm{DH}}=\mu_{\mathrm{EH}} \\
& \mathrm{H}_{1:} \mu_{\mathrm{DH}} \neq \mu_{\mathrm{EH}}
\end{aligned}
$$

$\mu_{\mathrm{EH}}$ is the average existing amount of human skills.

Desirable amount of human skills is the average of desirable amount of indices that are settled in the human skills category based on the results of hypotheses (a).

Existing amount of human skills is the average of existing amount of indices that are settled in the human skills category based on the results of hypotheses (a).

Hypothesis (e): $\mathrm{H}_{0}$ : there is no difference between the average of desirable amount and the average of existing amount of key users' conceptual skills. (There is not conceptual skills shortage) $\mathrm{H}_{1}$ : there is a difference between the average of desirable amount and the average of existing amount of key users' conceptual skills. (There is conceptual skills shortage).

$\mathrm{H}_{0:} \mu_{\mathrm{DC}}=\mu_{\mathrm{EC}}$
$\mathrm{H}_{1:} \mu_{\mathrm{DC}} \neq \mu_{\mathrm{EC}}$

$\mu_{\mathrm{EC}}$ is the average existing amount of conceptual skills. 
Table 3 Result of chi-square test

${ }^{4} \mathrm{p}$-value for $\mathrm{P}_{\mathrm{T}}=\mathrm{P}_{\mathrm{H}}=\mathrm{P}_{\mathrm{C}}$

${ }^{5} \mathrm{p}$-value for $\mathrm{P}_{\mathrm{i}}=\mathrm{P}_{\mathrm{j}} \mathrm{i} \neq \mathrm{j} \mathrm{i}, \mathrm{j}=\mathrm{T}, \mathrm{H}, \mathrm{C}$

Table 4 The place of each index in main categories of technical, human and conceptual skills.

\begin{tabular}{|c|c|c|c|c|c|}
\hline No. & Index & Sig. ${ }^{4}$ & Sig. ${ }^{5}$ & & test result \\
\hline 1 & Change Management & $\leq 0.05$ & $\mathrm{P}_{\mathrm{C}}=\mathrm{P}_{\mathrm{H}}$ & 0.63 & $\mathrm{P}_{\mathrm{C}}=\mathrm{P}_{\mathrm{H}}>\mathrm{P}_{\mathrm{T}}$ \\
\hline 2 & Stress Management & $\leq 0.05$ & & & $\mathrm{P}_{\mathrm{H}}>\mathrm{P}_{\mathrm{T}}, \mathrm{P}_{\mathrm{C}}$ \\
\hline 3 & Technology Management Knowledge & $\leq 0.05$ & & & $\mathrm{P}_{\mathrm{T}}>\mathrm{P}_{\mathrm{H}}, \mathrm{P}_{\mathrm{C}}$ \\
\hline 4 & Project Management & $\leq 0.05$ & & & $\mathrm{P}_{\mathrm{T}}>\mathrm{P}_{\mathrm{H}}=\mathrm{P}_{\mathrm{C}}$ \\
\hline 5 & Information Literacy & $\leq 0.05$ & $\mathrm{P}_{\mathrm{C}}=\mathrm{P}_{\mathrm{T}}$ & 0.24 & $\mathrm{P}_{\mathrm{C}}=\mathrm{P}_{\mathrm{T}}>\mathrm{P}_{\mathrm{H}}$ \\
\hline 6 & Negotiation and Conflict Management & $\leq 0.05$ & & & $\mathrm{P}_{\mathrm{H}}>\mathrm{P}_{\mathrm{T}=} \mathrm{P}_{\mathrm{C}}$ \\
\hline 7 & Risk Management & $\leq 0.05$ & & & $\mathrm{P}_{\mathrm{C}}>\mathrm{P}_{\mathrm{T}}, \mathrm{P}_{\mathrm{H}}$ \\
\hline 8 & Teaching and Training Skills & $\leq 0.05$ & $\mathrm{P}_{\mathrm{T}}=\mathrm{P}_{\mathrm{H}}$ & 0.26 & $\mathrm{P}_{\mathrm{T}}=\mathrm{P}_{\mathrm{H}}>\mathrm{P}_{\mathrm{C}}$ \\
\hline 9 & Crisis Management & $\leq 0.05$ & & & $\mathrm{P}_{\mathrm{C}}>\mathrm{P}_{\mathrm{T}}=\mathrm{P}_{\mathrm{H}}$ \\
\hline 10 & Organizing & 0.06 & & & $\mathrm{P}_{\mathrm{C}}=\mathrm{P}_{\mathrm{T}}=\mathrm{P}_{\mathrm{H}}$ \\
\hline 11 & Leadership Skills & $\leq 0.05$ & & & $\mathrm{P}_{\mathrm{H}}>\mathrm{P}_{\mathrm{T}}, \mathrm{P}_{\mathrm{C}}$ \\
\hline 12 & ERP Technical Knowledge & $\leq 0.05$ & & & $\mathrm{P}_{\mathrm{T}}>\mathrm{P}_{\mathrm{H}}=\mathrm{P}_{\mathrm{C}}$ \\
\hline 13 & General Skills & $\leq 0.05$ & & & $\mathrm{P}_{\mathrm{T}}>\mathrm{P}_{\mathrm{H},} \mathrm{P}_{\mathrm{C}}$ \\
\hline 14 & Business Processes Knowledge & $\leq 0.05$ & $\mathrm{P}_{\mathrm{C}}=\mathrm{P}_{\mathrm{T}}$ & 0.82 & $\mathrm{P}_{\mathrm{C}}=\mathrm{P}_{\mathrm{T}}>\mathrm{P}_{\mathrm{H}}$ \\
\hline 15 & Analytical Skills & $\leq 0.05$ & & & $\mathrm{P}_{\mathrm{C}}>\mathrm{P}_{\mathrm{T}}=\mathrm{P}_{\mathrm{H}}$ \\
\hline 16 & Team Skills & $\leq 0.05$ & & & $\mathrm{P}_{\mathrm{H}}>\mathrm{P}_{\mathrm{T}}=\mathrm{P}_{\mathrm{C}}$ \\
\hline 17 & Personal Skills & $\leq 0.05$ & & & $\mathrm{P}_{\mathrm{H}}>\mathrm{P}_{\mathrm{T}}, \mathrm{P}_{\mathrm{C}}$ \\
\hline 18 & Strategic Planning & $\leq 0.05$ & & & $\mathrm{P}_{\mathrm{C}}>\mathrm{P}_{\mathrm{T}}, \mathrm{P}_{\mathrm{H}}$ \\
\hline 19 & System Skills & $\leq 0.05$ & & & $\mathrm{P}_{\mathrm{C}}>\mathrm{P}_{\mathrm{T}}=\mathrm{P}_{\mathrm{H}}$ \\
\hline 20 & Communication Skills & $\leq 0.05$ & & & $\mathrm{P}_{\mathrm{H}}>\mathrm{P}_{\mathrm{T}}=\mathrm{P}_{\mathrm{C}}$ \\
\hline 21 & Time Management & $\leq 0.05$ & $\mathrm{P}_{\mathrm{C}}=\mathrm{P}_{\mathrm{T}}$ & 0.067 & $\mathrm{P}_{\mathrm{C}}=\mathrm{P}_{\mathrm{T}}>\mathrm{P}_{\mathrm{H}}$ \\
\hline 22 & Decision Making and Problem Solving Skills & $\leq 0.05$ & & & $\mathrm{P}_{\mathrm{C}}>\mathrm{P}_{\mathrm{H}}, \mathrm{P}_{\mathrm{T}}$ \\
\hline
\end{tabular}

\begin{tabular}{lll}
\hline No. & Index & Category(s) \\
\hline 1 & Change Management & human, conceptual \\
2 & Stress Management & Human \\
3 & Technology Management Knowledge & technical \\
4 & Project Management & Technical \\
5 & Information Literacy & conceptual, technical \\
6 & Negotiation and Conflict Management & Human \\
7 & Risk Management & Conceptual \\
8 & Teaching and Training Skills & human, technical \\
9 & Crisis Management & Conceptual \\
10 & Organizing & conceptual, technical, human \\
11 & Leadership Skills & Human \\
12 & ERP Technical Knowledge & Technical \\
13 & General Skills & technical \\
14 & Business Processes Knowledge & conceptual, technical \\
15 & Analytical Skills & Conceptual \\
16 & Team Skills & Human \\
17 & Personal Skills & Human \\
18 & Strategic Planning & Conceptual \\
19 & System Skills & Conceptual \\
20 & Communication Skills & Human \\
21 & Time Management & conceptual, technical \\
22 & Decision Making and Problem Solving Skills & Conceptual \\
\hline & &
\end{tabular}


Table 5 The results of factor analysis

\begin{tabular}{|c|c|c|c|c|}
\hline \multirow[t]{2}{*}{ No. } & \multirow[t]{2}{*}{ Index } & \multicolumn{3}{|c|}{ Component } \\
\hline & & 1 & 2 & 3 \\
\hline 1 & Technology Management Knowledge & .796 & .330 & .152 \\
\hline 2 & ERP Technical Knowledge & .745 & .275 & .178 \\
\hline 3 & General Skills & .708 & .343 & .265 \\
\hline 4 & Teaching and Training Skills & 697 & .244 & .308 \\
\hline 5 & Information Literacy & .639 & .150 & .523 \\
\hline 6 & Leadership Skills & .604 & .406 & .369 \\
\hline 7 & Time management & .559 & .507 & .346 \\
\hline 8 & Project management & .535 & .494 & .264 \\
\hline 9 & Business Processes Knowledge & .506 & .392 & .358 \\
\hline 10 & Crisis Management & .223 & .786 & .286 \\
\hline 11 & Strategic Planning & .364 & .752 & .181 \\
\hline 12 & Decision Making and Problem Solving Skills & .218 & .726 & .403 \\
\hline 13 & Organizing & .432 & .700 & .125 \\
\hline 14 & Risk Management & .338 & .693 & .292 \\
\hline 15 & Analytical Skills & .245 & .635 & .502 \\
\hline 16 & Change Management & .207 & .315 & .799 \\
\hline 17 & Negotiation and Conflict Management & .199 & .211 & .759 \\
\hline 18 & System Skills & .374 & .371 & .591 \\
\hline 19 & Communication Skills & .525 & .150 & .564 \\
\hline 20 & Team Skills & .280 & .537 & .556 \\
\hline 21 & Personal Skills & .415 & .361 & .504 \\
\hline 22 & Stress Management & .365 & .454 & .504 \\
\hline
\end{tabular}

Desirable amount of conceptual skills is the average of desirable amount of indices that are settled in the conceptual skills category based on the results of hypotheses (a).

Existing amount of conceptual skills is the average of existing amount of indices that are settled in the conceptual skills category based on the results of hypotheses (a).

Paired samples test was used to test hypotheses (c), (d), and (e). This test was used given that respondents were similar in both groups.

Furthermore, due to the existence of skills shortages (see section 4), a comparison between SMEs and large companies has been made to investigate key users in which kind of companies suffers more from skills shortages. Thus the following hypothecs (f) are proposed:

$\mathrm{H}_{0:} \mathrm{D}_{\text {TLarge }}=\mathrm{D}_{\text {TSMEs }} \quad \mathrm{H}_{1}: \mathrm{D}_{\text {TLarge }} \neq \mathrm{D}_{\text {TSMEs }}$

$\mathrm{D}_{\text {TLarge: }}$ the average of technical skills shortage of key users in large companies

$\mathrm{D}_{\text {TSMEs: }}$ the average of technical skills shortage of key users in SMEs

$\mathrm{H}_{0}$ : $\mathrm{D}_{\text {HLarge }}=\mathrm{D}_{\text {HSMEs }} \quad \mathrm{H}_{1}$ : $\mathrm{D}_{\text {HLarge }} \neq \mathrm{D}_{\text {HSMEs }}$

$\mathrm{D}_{\text {HLarge: }}$ the average of human skills shortage of key users in large companies

$D_{\text {HSMEs: }}$ the average of human skills shortage of key users in SMEs

$\mathrm{H}_{0:} \mathrm{D}_{\text {CLarge }}=\mathrm{D}_{\text {CSMEs }} \quad \mathrm{H}_{1}: \mathrm{D}_{\text {CLarge }} \neq \mathrm{D}_{\text {CSMEs }}$
Table 6 Mauchly's Test of Sphericity

\begin{tabular}{lllllllll}
\hline Within Subjects & $\begin{array}{l}\text { Mauchly's } \\
\text { Effect }\end{array}$ & Approx. Chi- & df & Sig. & Epsilon & & \\
\cline { 5 - 7 } & & & & & $\begin{array}{l}\text { Greenhouse- } \\
\text { Geisser }\end{array}$ & $\begin{array}{l}\text { Huynh- } \\
\text { Feldt }\end{array}$ & $\begin{array}{l}\text { Lower- } \\
\text { bound }\end{array}$ \\
\hline factor1 & .965 & 3.745 & 2 & .154 & .966 & .984 & .500 \\
\hline
\end{tabular}


Table 7 Tests of Within-Subjects Effects

\begin{tabular}{llllll}
\hline Source & & Type III Sum of Squares & Df & Mean Square & F \\
\hline factor1 & Sphericity Assumed & 4.281 & 2 & 2.141 & 14.609 \\
& Greenhouse-Geisser & 4.281 & 1.932 & 2.216 & .000 \\
& Huynh-Feldt & 4.281 & 1.967 & 2.176 & .000 \\
& Lower-bound & 4.281 & 1 & 4.281 & .000 \\
Error(factor1) & Sphericity Assumed & 30.771 & 210 & 0.147 & .000 \\
& Greenhouse-Geisser & 30.771 & 202.826 & 0.152 & 14.609 \\
& Huynh-Feldt & 30.771 & 206.558 & 0.149 & 0.293 \\
\hline
\end{tabular}

$\mathrm{D}_{\text {CLarge: }}$ the average of conceptual skills shortage of key users in large companies

$\mathrm{D}_{\text {CSMEs: }}$ the average of conceptual skills shortage of key users in SMEs

Another examination in this study is whether the skills shortage of key users in three main categories of technical, human, and conceptual skills, in each of large companies and SMEs, is the same or not. Thus the below hypothecs are proposed:

$$
\begin{aligned}
\mathrm{H}_{0:} \mathrm{D}_{\text {TLarg }}= & \mathrm{D}_{\text {HLarge }}=\mathrm{D}_{\text {CLarge }} \\
& \mathrm{H}_{1}: \text { otherwise } \\
\mathrm{H}_{0:} \mathrm{D}_{\text {TSMEs }}= & \mathrm{D}_{\text {HSMEs }}=\mathrm{D}_{\text {CSMEs }} \\
& \mathrm{H}_{1}: \text { otherwise }
\end{aligned}
$$

Repeated measures test (within-subjects effects test) was used given that respondents were similar in each of the three groups.

Table 8 Results of paired samples test

\begin{tabular}{lll}
\hline Hypothesis & & Sig. (2-tailed) \\
\hline $\mathrm{H}_{0:} \mu_{\mathrm{DT}}=\mu_{\mathrm{DH}}$ & $\begin{array}{c}\text { Pair } 1 / \text { Desirable amount of } \\
\text { technical skills- Desirable } \\
\text { amount of human skills }\end{array}$ & 0.000 \\
& $\begin{array}{l}\text { Pair } 2 / \text { Desirable amount of } \\
\text { technical skills- Desirable } \\
\mathrm{H}_{0:} \mu_{\mathrm{DT}}=\mu_{\mathrm{DC}}\end{array}$ & 0.000 \\
& $\begin{array}{l}\text { amount of conceptual skills } \\
\text { Pair 3/ Desirable amount of } \\
\text { human skills- Desirable } \\
\text { amount of conceptual skills }\end{array}$ & 0.478 \\
&
\end{tabular}

\section{Data analysis}

This section is stated in two parts given that the present research includes two parts.

\subsection{Data analysis of the first part}

Table 3 is a summary of results related to chi-square test for testing hypotheses (a) which illustrates that each of the indices in Table 2 is settled in which main categories of technical, human, and conceptual skills.

About results obtained from classification of indices, it is noteworthy that belonging of an index to two or more categories of major skills does not mean that its degree of dependence to those major categories is similar; or an index which belongs to one or two categories does not mean it does not belong to other category or categories, rather it has less dependence degree than categories in which it has not been settled based on average views of experts.

Process of the accomplished analyses is in the way that first $\mathrm{P}_{\mathrm{T}}=\mathrm{P}_{\mathrm{H}}=\mathrm{P}_{\mathrm{C}}$ test is performed for each index. If $p$ value is less than 0.05, hypothesis $\mathrm{P}_{\mathrm{T}}=\mathrm{P}_{\mathrm{H}}=\mathrm{P}_{\mathrm{C}}$ is rejected and existence of significant difference among the ratios is confirmed and pairwise comparison has to be done. So, the following

Table 9 The average of desirable amount of the main categories according to descriptive statistics

\begin{tabular}{ll}
\hline Skills & The average of desirable amount \\
\hline Technical & 8.22 \\
Human & 8.48 \\
Conceptual & 8.45 \\
\hline
\end{tabular}


Table 10 Descriptive Statistics: average and standard deviation of indices

\begin{tabular}{llll}
\hline No. & Skill & Mean & Std. Deviation \\
\hline 1 & Personal Skills & 8.896 & 1.032 \\
2 & Team Skills & 8.83 & 1.214 \\
3 & System Skills & 8.773 & 1.244 \\
4 & Organizing & 8.735 & 1.557 \\
5 & Decision Making and Problem Solving Skills & 8.613 & 1.261 \\
6 & Strategic Planning & 8.584 & 1.45 \\
7 & Change Management & 8.547 & 1.243 \\
8 & Business Processes Knowledge & 8.528 & 1.358 \\
9 & Analytical Skills & 8.49 & 1.29 \\
10 & Communication Skills & 8.49 & 1.462 \\
11 & Leadership Skills & 8.481 & 1.346 \\
12 & General Skills & 8.452 & 1.435 \\
13 & Information Literacy & 8.377 & 1.588 \\
14 & Negotiation and Conflict Management & 8.358 & 1.55 \\
15 & Crisis Management & 8.141 & 1.753 \\
16 & Time Management & 8.132 & 1.627 \\
17 & Technology Management Knowledge & 8.113 & 1.669 \\
18 & Teaching and Training Skills & 8.0566 & 1.535 \\
19 & Risk Management & 8 & 1.817 \\
20 & Stress Management & 7.962 & 1.701 \\
21 & Project Management & 7.877 & 2.078 \\
22 & ERP Technical Knowledge & 7.726 & 1.973 \\
\hline
\end{tabular}

hypothesis is tested for each two ratios:

$P_{i}=P_{j} \quad i \neq j \quad i, j=T, H, C$

In the Table 3, $p$ values related to comparison of two ratios that have the highest amount and based on test are equal to each other are shown in column four. Based on Table 3, Table 4 shows that each index is settled more

Table 11 Results of paired samples test for testing hypotheses (c), (d) and (e)

\begin{tabular}{lll}
\hline Hypothesis & & Sig. (2-tailed) \\
\hline (c) & $\begin{array}{c}\text { Pair 1/ Desirable amount of } \\
\text { technical skills -Existing }\end{array}$ & 0.000 \\
& $\begin{array}{l}\text { amount of technical skills } \\
\text { (d) } \quad \begin{array}{c}\text { Pair 2/ Desirable amount of } \\
\text { human skills - Existing }\end{array}\end{array}$ & 0.000 \\
& amount of human skills & \\
(e) & $\begin{array}{l}\text { Pair 3/ Desirable amount of } \\
\text { conceptual skills- Existing } \\
\end{array}$ & 0.000 \\
& amount of conceptual skills & \\
\hline
\end{tabular}

in which main categories of technical, human, and conceptual skills.

As mentioned in Section 3, factor analysis method was used in this part to confirm the experts' opinion. The factor analysis confirms nearly $90 \%$ of the experts' opinion. The results of factor analysis are shown in Table 5.

As it shows, leadership and system skills are not in the categories which the experts have assigned for these skills.

\subsection{Data analysis of the second part}

Hypothesis (b) is tested in the following and purpose of this hypothesis is to answer to the question whether importance

Table 12 T-Test for equality of means of SMEs and large companies in each of technical, human, conceptual skills shortage

\begin{tabular}{lll}
\hline Hypothesis & Variable & Sig. (2-tailed) \\
\hline (f) & Technical Skills Shortage & 0.045 \\
(f) & Human Skills Shortage & 0.031 \\
(f) & Conceptual Skills Shortage & 0.001 \\
\hline
\end{tabular}


Table 13 The average of skills shortage in SMEs and Large Companies

\begin{tabular}{lll}
\hline & Large Companies & SMEs \\
\hline Skills Shortages & Mean & Mean \\
Technical Skills Shortage & 3.21 & 2.57 \\
Human Skills Shortage & 3.36 & 2.69 \\
Conceptual Skills Shortage & 3.57 & 2.55 \\
\hline
\end{tabular}

level of technical, human and conceptual skills is identical for key users or not. Test results are illustrated in Tables 6 and 7.

Mauchly sphericity test was performed to examine homogeneity of covariance assumption. Since the amount of $p$ value for Mauchly sphericity test is more than 0.05 , the $p$ value presented in Sphericity assumed row was used to test withinsubjects effects. Hypothesis $\mathrm{H} 0$ is rejected due to amount of $p$ value $<0.05$. It means that importance level of technical, human, and conceptual skills is not identical. (It is noteworthy that this result was observed in both large companies and SMEs). Now in order to determine which main category has more importance, paired samples test is applied for pairwise comparison of these skills. Table 8 shows summary of the test results.

Existence of significant difference between technical skill with two conceptual and human skills is confirmed at significance level 0.05 given to $p$ value amounts. Moreover, descriptive statistics and comparison of the average of desirable amounts of these three skills groups show that human and conceptual skills have more importance than technical skills for key users (see Table 9, the column related to the average of desirable amount).

Also the most important skills of key users are indicated in Table 10, respectively, based on descriptive statistics (Indices with the most desirable amounts).

Table 11 has illustrated a summary of paired samples test results for testing hypotheses (c), (d), and (e) that study the difference between existing amount and desirable amount of skills (skill shortage) of key users in each category.

According to Table 11, it has been specified that desirable amount and existing amount of skills of key users under study have significant difference in each of the three main categories of technical, human, and conceptual skills. In other words, there is skills shortage in each of the three main categories. (It is noteworthy that this result was observed in both large companies and SMEs).

To determine which kind of companies suffers more from skills shortages, a comparison between SMEs and large companies has been made. The results of independent samples $t$ test used in this part are shown in Table 12 .

For $p$ values $<0.05$, hypothesis $\mathrm{H} 0$ is rejected. This means that the amount of technical skills shortages, human skills shortages and conceptual skills shortages are not equal in SMEs and large companies. According descriptive statistics, there are more skills shortages in large companies (Table 13).

Next question is that whether the amount of skills shortages of key users in each of the three categories of technical,

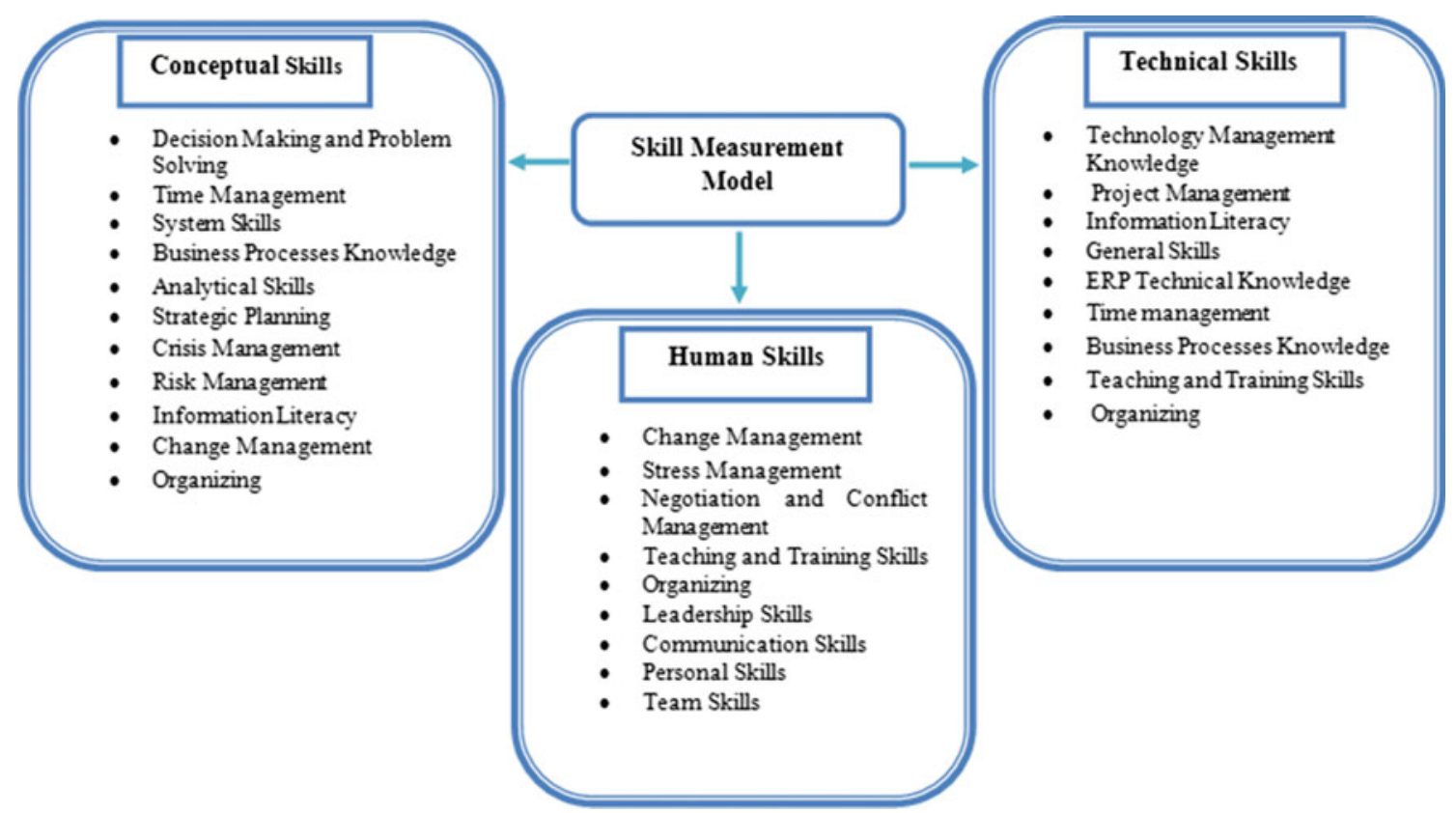

Fig. 2 Skill measurement model in ERP implementation project 
Table 14 Mauchly's Test of Sphericity (SMEs)

\begin{tabular}{llllllll}
\hline $\begin{array}{l}\text { Within Subjects } \\
\text { Effect }\end{array}$ & $\begin{array}{l}\text { Mauchly's } \\
\text { W }\end{array}$ & $\begin{array}{l}\text { Approx. Chi- } \\
\text { Square }\end{array}$ & df & Sig. & & Epsilon & \\
\cline { 5 - 7 } & & & & $\begin{array}{l}\text { Greenhouse- } \\
\text { Geisser }\end{array}$ & $\begin{array}{l}\text { Huynh- } \\
\text { Feldt }\end{array}$ & $\begin{array}{l}\text { Lower- } \\
\text { bound }\end{array}$ \\
\hline factor1 & 0.932 & 3.794 & 2 & 0.150 & 0.936 & 0.968 & .500 \\
\hline
\end{tabular}

human, and conceptual skills is the same or not. Thus hypothesis $(\mathrm{g})$ is tested for large companies and SMEs separately and results are illustrated in Tables 14, 15, 16 and 17.

For SMEs, given to amount of $p$ value (0.57), hypothesis $\mathrm{H} 0$ is accepted which means that the skills shortages of key users in the three main categories are equal. For large companies, $p$ value $(0.001)<0.05$ means the skills shortages of key users in the three main categories are not equal. As paired samples test and Table 13 show, conceptual skills shortage is more than other main skills categories in large companies (Table 18).

\section{Discussion}

Successful implementation of ERP systems requires a multilateral study of organizational readiness and establishment of appropriate technical, human, and cultural infrastructures. In this study, one of the most important factors among these, i.e., human factor has been considered and due to the presence and role of key users in the different stages of ERP life cycle, it is examined to see what skills are the most important for key users and whether these users have adequate technical, human, and conceptual skills for implementation of such system in the organizations under study or not. In this regard, given to experts' opinion, the following model shown in Fig. 2 has been established to determine and measure skills required by team members involved in ERP implementation project such as key users as well as measure skills shortages of them.

According to data analysis, human and conceptual skills are determined as the most important skills of key users in ERP implementation. It could be stated given to the role of key users and the nature and goals of ERP system.

Key users in the organization are usually middle managers and user representatives who should have necessary human skills. More explanations will be provided in the following. One of the important cases in successful ERP implementation is acceptance of the system and reduction of resistance to changes arising from implementation of this system. Role of key users as a facilitator and change agent is very valuable. These users must have necessary skills in the field of management and leadership of changes and be familiar with principles and strategies of change management. They should be justified well at first and perceive change reasons in order to act as a good change agent. Furthermore, key users not only are a member of ERP implementation team, but also they must constitute a team of end users in their domain and manage it well. So, key users should have the ability to establish cooperation and work effectively in the group and know how to perceive and behave towards those around them such as project managers, colleagues, and end users as well as implementation consultants. A prominent factor in ERP implementation is the appropriate relationship among consultants and the organization. King [88] found that communication and knowledge exchange between the key

Table 15 Tests of Within-Subjects Effects(SMEs)

\begin{tabular}{lllllr}
\hline Source & & Type III Sum of Squares & Df & Mean Square & F \\
\hline factor1 & Sphericity Assumed & 0.316 & 2 & 0.158 & .565 \\
& Greenhouse-Geisser & 0.316 & 1.873 & 0.169 & 0.570 \\
& Huynh-Feldt & 0.316 & 1.937 & 0.163 & .565 \\
Error(factor1) & Lower-bound & 0.316 & 1 & 0.316 & .565 \\
& Sphericity Assumed & 30.716 & 110 & 0.260 & .565 \\
& Greenhouse-Geisser & 30.716 & 103.010 & 0.271 & 0.455 \\
& Huynh-Feldt & 30.716 & 106.510 & 0.266 \\
\end{tabular}


Table 16 Mauchly's Test of Sphericity (Large companies)

\begin{tabular}{llllllll}
\hline $\begin{array}{l}\text { Within Subjects } \\
\text { Effect }\end{array}$ & $\begin{array}{l}\text { Mauchly's } \\
\text { W }\end{array}$ & $\begin{array}{l}\text { Approx. Chi- } \\
\text { Square }\end{array}$ & df & Sig. & & Epsilon & \\
\cline { 5 - 7 } & & & & $\begin{array}{l}\text { Greenhouse- } \\
\text { Geisser }\end{array}$ & $\begin{array}{l}\text { Huynh- } \\
\text { Feldt }\end{array}$ & $\begin{array}{l}\text { Lower- } \\
\text { bound }\end{array}$ \\
\hline factor1 & 0.921 & 3.712 & 2 & 0.156 & 0.927 & 0.964 & .500 \\
\hline
\end{tabular}

users and consultants is the crucial factor for the ERP implementation success. Indeed key users are a bridge between the organization and consultants. Therefore, they must have strong team and communication skills. Among the other noteworthy cases is that the organization must emphasize personal skills of key users while selecting them. Key users as user representatives should have motivation, acceptance of responsibility, trustworthiness, creative thinking, adaptability, and flexibility to be accepted and trusted by their group. As a result, according to Kotter [89], human skills are especially needed during changes. The importance of human skills has also been mentioned as a deliverer of technical and conceptual aspects [34].

Conceptual skills are determined as other important skills for key users. It can be explained given to underlying philosophy of ERP systems that their major purpose is to create integration in the whole organization. ERP software solutions address the issues facing some organizations with a functional structure. In these organizations, each functional unit works towards their own goals and objectives, rather than the organizational goals. Moreover, information flow is restricted by functions, and even when other functional units want to take a systemic view, they do not have the needed information to do so [90]. Namely, ERP systems are usually acquired to enhance efficient cross-functional operations within the adopting organization [91]. All business processes of an organization are involved in ERP systems. The adopted ERP system will influence all business operations, even strategies, in the future [1]. Also, support of strategic planning and decision making are other goals of ERP system [2]. Therefore, it brings a need for key users to have sufficient conceptual skills to use the ERP system properly. As mentioned earlier, conceptual skills can be thought of as the "thinking skills." This type of skill involves being able to see both what is going on within an entire organization, and how the various parts of the organization interact and depend on one another [49].

The results of this research show that unfortunately key users of ERP systems do not have adequate technical, human and conceptual skills in the organizations under study. This could be one of the failure reasons of ERP implementation projects in the Iranian organizations. The reasons of skills shortages of key users were determined through sending a questionnaire including 10 potential reasons to some managers of organizations. The most important reasons of these skills shortages are as follows, respectively: Inadequate training, poor training, wrong selection of key users, lack of motivation to use the system and displacement of key users. Furthermore, researchers conducted interviews with some managers of the organizations under study and the following human factors have been stated as some associated problems in ERP implementation. Lack of reward and motivation, the users' untimely notification of their needs, employees' dissatisfaction with their job, lack of individuals who dominate business processes, lack of sufficient system skills in key users, the task-oriented mentality instead of process-oriented mentality in individuals, improper perception of ERP and lack of interpretation power of the system, the individuals' insufficient knowledge in the organization, individuals' reluctance to planning, full time unavailability of key users at the time of system implementation, selection of key users without considering their knowledge and abil-

Table 17 Tests of Within-Subjects Effects (Large companies)

\begin{tabular}{|c|c|c|c|c|c|c|}
\hline Source & & Type III Sum of Squares & Df & Mean Square & $\mathrm{F}$ & Sig. \\
\hline \multirow[t]{4}{*}{ factor1 } & Sphericity Assumed & 3.081 & 2 & 1.540 & 7.235 & 0.001 \\
\hline & Greenhouse-Geisser & 3.081 & 1.853 & 1.662 & 7.235 & 0.002 \\
\hline & Huynh-Feldt & 3.081 & 1.928 & 1.598 & 7.235 & 0.001 \\
\hline & Lower-bound & 3.081 & 1 & 3.081 & 7.235 & 0.01 \\
\hline \multirow[t]{4}{*}{ Error(factor1) } & Sphericity Assumed & 19.588 & 92 & 0.213 & & \\
\hline & Greenhouse-Geisser & 19.588 & 85.251 & 0.230 & & \\
\hline & Huynh-Feldt & 19.588 & 88.676 & 0.221 & & \\
\hline & Lower-bound & 19.588 & 46 & 0.426 & & \\
\hline
\end{tabular}


Table 18 Results of Paired Samples Test (Large companies)

\begin{tabular}{|c|c|c|}
\hline \multicolumn{2}{|l|}{ Hypothesis } & \multirow{2}{*}{$\frac{\text { Sig. (2-tailed) }}{0.165}$} \\
\hline $\mathrm{H}_{0:} \mathrm{D}_{\mathrm{TLarge}}=\mathrm{D}_{\text {HLarge }}$ & $\begin{array}{l}\text { Pair 1/ Technical Skills } \\
\text { Shortages - Human } \\
\text { Skills Shortages }\end{array}$ & \\
\hline $\mathrm{H}_{0:} \mathrm{D}_{\text {TLarge }}=\mathrm{D}_{\text {CLarge }}$ & $\begin{array}{l}\text { Pair 2/ Technical Skills } \\
\text { Shortages - Conceptual } \\
\text { Skills Shortages }\end{array}$ & 0.000 \\
\hline $\mathrm{H}_{0:} \mathrm{D}_{\text {CLarge }}=\mathrm{D}_{\text {HLarge }}$ & $\begin{array}{l}\text { Pair 3/ Conceptual Skills } \\
\text { Shortages - Human } \\
\text { Skills Shortages }\end{array}$ & 0.015 \\
\hline
\end{tabular}

ities, impatience for obtaining results, discontinuous and inadequate training, displacement of key users and personnel after training the system to them, the high average age of individuals, key users' intention to being told what to do and then delegating the activities to subordinates, nonparticipation of some of the selected key users in implementation project, and lack of management art in some key users.

The above issues indicate necessity of appropriate selection of key users as well as holding educational courses in order to enhance skills of key users in Iranian organizations. Although there are other techniques such as increased wages, substituting labor, overseas recruitment to alleviate skills shortages, education, and training will have the biggest longterm impact on skills shortages [27]. Training is one of the critical success factors mentioned in many researches. Through a literature review of critical success factors in ERP implementation across ten different countries/regions E. Ngai et al. [92] identified $18 \mathrm{CSFs}$ with more than 80 sub-factors for successful implementation of ERP. In these 18 CSFs, "top management support" and "training and education" were the most frequently cited as critical factors with regard to successful implementation of ERP systems in all regions and countries. Moreover, Skill gaps could arise as a consequence of poor education infrastructures. Poor education infrastructures lead individuals to devote insufficient effort to learning in order to update their knowledge [30].

\section{Practical implications}

The data from this study reveals several practical implications. First, insights regarding skills needs and skills shortages of key users can help management take appropriate actions. Due to increasing demand for enterprise systems in organizations and also the role of key users, more attention is needed to avoid skills shortages of these users. Managers and labor leaders should see the issue of skills shortages as a threat for ERP success and be concerned about that. They should pay more attention regarding selection and training of key users as well as other individuals who play a role in ERP implementation. Developing long-term strategies for alleviating these shortages would be valuable. A collaborative skills shortage planning and management system shared between government, companies, education, and other relevant organizations could significantly impact on reduction of skill shortages. Also, since the installed ERP system is not ending but instead is continuously working and improving over time [1], policies that address skills deficiencies will only be successful if they produce a continual, rather than a temporary, increase in levels of skills among the workforce[31].

Skill shortages are currently widening across countries and industries [30]. So, the results of the present survey should be useful not only for Iranian organizations but also for all companies that are using this system or intend to implement such system, specially companies in developing countries.

Second, our research developed a model that could be used to determine the requisite skills and measure skills shortages of those individuals who are dealing with this system such as project managers, IT experts, key users, end users, and consultants. By means of this model it is possible to measure desirable level of technical, human and conceptual skills that individuals with similar position expected to have from one side and degree of such skills that presently these people have from the other side. Then by comparing these two amounts, the skill shortages of people under study can be determined. Moreover, skills with the most desirable amounts are the most important skills required by these individuals. This issue could be considered before ERP implementation to evaluate one of the organization's readiness indices for ERP implementation, i.e. skill and knowledge of human forces. Undoubtedly, identifying and evaluating skills needs and skills shortages and then providing strategies to improve the skill qualifications are necessary for companies which intend to use new complex technologies such as ERP. Moreover, because almost all organizational jobs need each one of technical, human and conceptual skills to some extent, the mentioned model could be utilized in other projects and organizations with a few changes. It is noteworthy that since this research was considered significantly by respondents, its conclusions were represented in a report form to the interested organizations.

\section{Limitations}

There are a few companies which have implemented ERP in Iran (less than 25 organizations). Moreover, a few people in organizations were able to response the research question- 
naire due to the topic under study, financial limitation of arranging for trip to some far regions, noncooperation of some organizational managers for research activities, and being busy and noncooperation of respondents in filling out the questionnaires were other limitations leaded to unavailability of more samples include. Furthermore, since measuring skill level of individuals is a personal question and is directly related to the respondents, some respondents might have specified their skills beyond reality. So, this is one of the issues which may have affected results of this study.

\section{Conclusion}

The present study tried to consider one of the most effective factors in ERP implementation, i.e., competency of stakeholders who are taking part in the process of ERP implementation. Although, many researchers have pointed the importance of knowledge, skills, abilities, and experience of project team in ERP implementation, there are far few studies have examined and focused on skill and skills shortages of individuals in ERP implementation. In this study, a comprehensive model was developed to measure requisite skills and skills shortages of people involved in ERP implementation such as key users. Then based on this model, thirteen Iranian organizations in which ERP has been implemented were examined to study skills of key users who have a significant role in ERP implementation. Results of data analysis show human and conceptual skills have more importance than technical skills for key users in ERP implementation. Also, eight important skills that key users must have are: Personal skills, team skills, system skills, organizing, decision making and problem solving skills, strategic planning, change management, and business processes knowledge. As it is observed, these skills are settled in the categories of human and conceptual skills. This study confirms key users are currently facing a severe skills shortage in each three categories (i.e., technical, human, and conceptual skills). Moreover, these users in large companies suffer more from skills shortages than ones in SMEs. This issue reveals importance of providing appropriate set of strategies such as holding educational and training courses in order to enhance key users' skills which can also have a remarkable impact on reduction of individuals' resistance to this valuable technology.

\section{Appendices}

Appendix 1. Questionnaire related to determining the place of each index in main categories (i.e. technical, human, and conceptual)

\begin{tabular}{|c|c|c|c|c|}
\hline No. & Index & $\begin{array}{l}\text { Technical } \\
\text { skills }\end{array}$ & $\begin{array}{l}\text { Human } \\
\text { skills }\end{array}$ & $\begin{array}{l}\text { Conceptual } \\
\text { skills }\end{array}$ \\
\hline 1 & Change Management & Technical & Human & Conceptual \\
\hline 2 & Stress Management & Technical & Human & Conceptual \\
\hline 3 & $\begin{array}{l}\text { Technology Management } \\
\text { Knowledge }\end{array}$ & Technical & Human & Conceptual \\
\hline 4 & Project Management & Technical & Human & Conceptual \\
\hline 5 & Information Literacy & Technical & Human & Conceptual \\
\hline 6 & $\begin{array}{l}\text { Negotiation and Conflict } \\
\text { Management }\end{array}$ & Technical & Human & Conceptual \\
\hline 7 & Risk Management & Technical & Human & Conceptual \\
\hline 8 & $\begin{array}{l}\text { Teaching and Training } \\
\text { Skills }\end{array}$ & Technical & Human & Conceptual \\
\hline 9 & Crisis Management & Technical & Human & Conceptual \\
\hline 10 & Organizing & Technical & Human & Conceptual \\
\hline 11 & Leadership Skills & Technical & Human & Conceptual \\
\hline 12 & ERP Technical Knowledge & Technical & Human & Conceptual \\
\hline 13 & General Skills & Technical & Human & Conceptual \\
\hline 14 & $\begin{array}{l}\text { Business Processes } \\
\text { Knowledge }\end{array}$ & Technical & Human & Conceptual \\
\hline 15 & Analytical Skills & Technical & Human & Conceptual \\
\hline 16 & Team Skills & Technical & Human & Conceptual \\
\hline 17 & Personal Skills & Technical & Human & Conceptual \\
\hline 18 & Strategic Planning & Technical & Human & Conceptual \\
\hline 19 & System Skills & Technical & Human & Conceptual \\
\hline 20 & Communication Skills & Technical & Human & Conceptual \\
\hline 21 & Time Management & Technical & Human & Conceptual \\
\hline 22 & $\begin{array}{l}\text { Decision Making and } \\
\text { Problem Solving Skills }\end{array}$ & Technical & Human & Conceptual \\
\hline
\end{tabular}

Appendix 2. Questionnaire related to measuring desirable and existing amount of each index

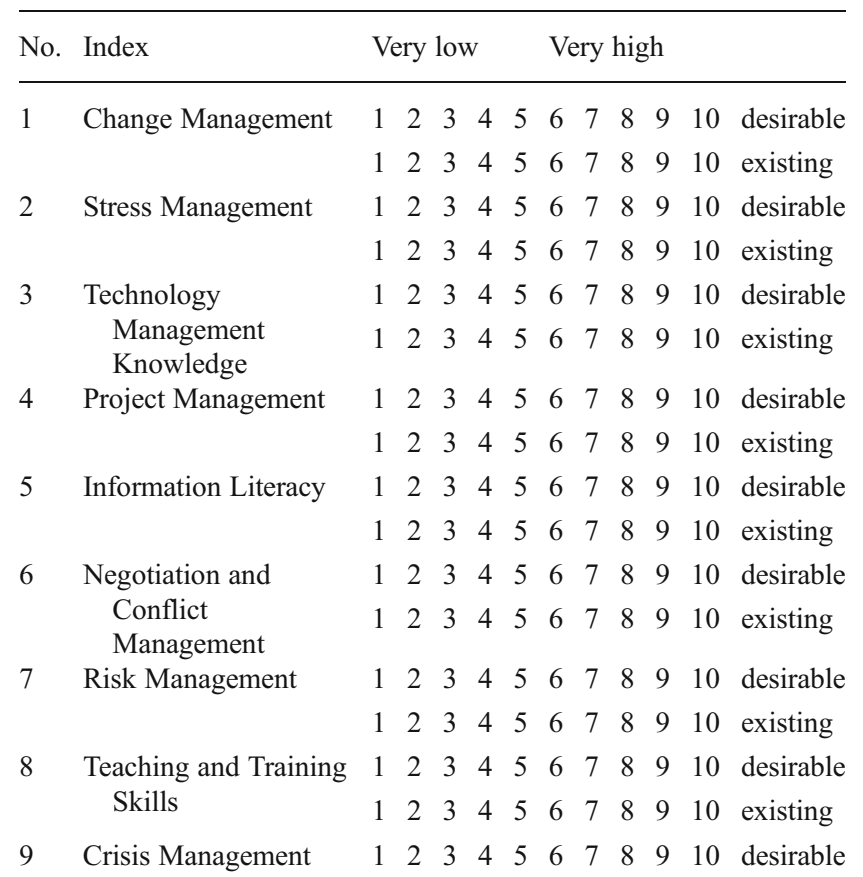


No. Index

Very low Very high

10 Organizing

$\begin{array}{lllllllllll}1 & 2 & 3 & 4 & 5 & 6 & 7 & 8 & 9 & 10 & \text { existing }\end{array}$

11 Leadership Skills

$\begin{array}{llllllllllll}1 & 2 & 3 & 4 & 5 & 6 & 7 & 8 & 9 & 10 & \text { desirable }\end{array}$

$\begin{array}{lllllllllll}1 & 2 & 3 & 4 & 5 & 6 & 7 & 8 & 9 & 10 & \text { existing }\end{array}$

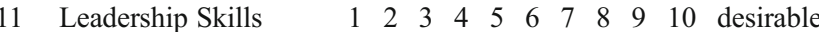

12 ERP Technical

Knowledge

13 General Skills

$\begin{array}{lllllllllll}1 & 2 & 3 & 4 & 5 & 6 & 7 & 8 & 9 & 10 & \text { existing }\end{array}$

$\begin{array}{lllllllllll}1 & 2 & 3 & 4 & 5 & 6 & 7 & 8 & 9 & 10 & \text { desirable }\end{array}$

$\begin{array}{lllllllllll}1 & 2 & 3 & 4 & 5 & 6 & 7 & 8 & 9 & 10 & \text { existing }\end{array}$

14 business Processes Knowledge

15 Analytical Skills

16 Team Skills

17 Personal Skills

18 Strategic Planning

19 System Skills

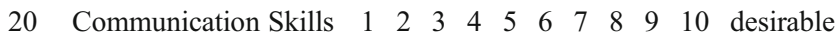
$\begin{array}{llllllllllll}1 & 2 & 3 & 4 & 5 & 6 & 7 & 8 & 9 & 10 & \text { existing }\end{array}$

21 Time Management $\quad \begin{array}{lllllllllll}1 & 2 & 3 & 4 & 5 & 6 & 7 & 8 & 9 & 10 & \text { desirable }\end{array}$ $\begin{array}{llllllllllll}1 & 2 & 3 & 4 & 5 & 6 & 7 & 8 & 9 & 10 & \text { existing }\end{array}$

22 Decision Making and $\begin{array}{lllllllllll}1 & 2 & 3 & 4 & 5 & 6 & 7 & 8 & 9 & 10 & \text { desirable }\end{array}$ Problem Solving $\quad \begin{array}{llllllllllll}1 & 2 & 3 & 4 & 5 & 6 & 7 & 8 & 9 & 10 & \text { existing }\end{array}$ Skills

Open Access This article is distributed under the terms of the Creative Commons Attribution License which permits any use, distribution, and reproduction in any medium, provided the original author(s) and the source are credited.

\section{References}

1. Wei CC (2007) Evaluating the performance of an ERP system based on the knowledge of ERP implementation objectives. Int $\mathrm{J}$ Adv Manuf Technol 39:168-181

2. Maditinos D, Chatzoudes D, Tsairidis C (2011) "Factors affecting ERP system implementation effectiveness". J Enterp Inf Manag 25(1):60-78

3. Davenport TH (1998) Putting the enterprise into the enterprise system. Harv Bus Rev 121-131

4. Stratman JK, Roth AV (2002) Enterprise resource planning (ERP) competence constructs: two-stage multi-item scale development and validation. Decis Sci 33(4):601-628

5. Beheshti HM (2006) "What managers should know about ERP/ ERP II". Manag Res News 29(4):184-193

6. Yu CS (2005) "Causes influencing the effectiveness of the postimplementation ERP system”. Ind Manag Data Syst 105(1):115-132

7. Bradley J (2008) Management based critical success factors in the implementation of Enterprise Resource Planning systems. Int $\mathrm{J}$ Account Inf Syst 9:175-200
8. Somers TM, Nelson KG (2001) "The Impact of Critical Success Factors across the Stages of Enterprise Resource Planning Implementations", Hawaii International Conference on Systems Sciences

9. Soja P (2006) Success factors in ERP systems Implementations: lessons from practice. J Enterp Inf Manag 19(4):418-433

10. Doom C, Milis K, Poelmans S, Bloemen E (2010) "Critical success factors for ERP implementations in Belgian SMEs". J Enterp Inf Manag 23(3):378-406

11. Upadhyay P, Jahanyan S, Dan PK (2011) Factors influencing ERP implementation in Indian manufacturing organisations: a study of micro, small and medium-scale enterprises. J Enterp Inf Manag 24(2):130-145

12. Sumner M (2000) Risk Factors in Enterprise-Wide/ERP Projects. J Inf Technol 15:317-327

13. Kumar V, Maheshwari B, Kumar U (2003) An investigation of critical management issues in ERP implementation: emperical evidence from Canadian organizations. Int $\mathrm{J}$ Technovation 23:793-807

14. Aloini D, Dulmin R, Mininno V (2007) "Risk management in ERP project introduction: Review of the literature". J Inf Manag 44:547-567

15. Hawari A, Heeks R (2010) Explaining ERP failure in a developing country: a Jordanian case study. J Enterp Inf Manag 23(2):135-160

16. Davenport TH (2000) Mission Critical: Realizing the Promise of Enterprise Systems. Harvard Business School Press, Boston, MA

17. Katzenbach JR, Smith DK (1998) The wisdom of teams creating the high performance organization. Harvard Business Review School Press, Boston, MA

18. Benders J (1995) "Output characteristics as input in the skilling debate". Work Employ Soc 9(2):329-342

19. Umble EJ, Umble M (2001) "Enterprise resource planning systems: a review of implementation issues and critical success factors", Proceedings of the 32nd Annual Meeting of the Decision Sciences Institute, pp. 1109-11

20. Nah FF, Lau JL, Kuang J (2001) Critical factors for successful implementation of enterprise systems. Bus Process Manag J 7(3):285-296

21. Al-Mashari M, Ghani SK, Al-Rashid W (2006) A study of the Critical Success Factors of ERP implementation in developing countries. Int J Internet Enterp Manag 4:68-95

22. Remus U (2006) "Classification of success factors for implementing enterprise portals". In: Tatnall A (ed) Encyclopedia of Portal Technologies and Applications. Idea Group, Hershey, PA

23. King SF, Burgess TF (2006) Beyond critical success factors: a dynamic model of enterprise system innovation. Int J Inf Manag 26:59-69

24. Green F, Machin S, Wilkinson D (1998) The meaning and determination of skill shortages. Oxf Bull Econ Stat 60:165-187

25. Bosworth DL, Dutton PA (1990) "Skill Shortages: an Overview". Int J Manpow 11(2):54-57

26. Fang T (2009) "Workplace responses to vacancies and skill shortages in Canada". Int J Manpow 30(4):326-348

27. Lobo YB, Wilkinson S (2008) "New approaches to solving the skills shortages in the New Zealand construction industry". Eng Constr Archit Manag 15(1):42-53

28. Senker P (1992) Skills shortages and Britain's international competitiveness. In: Bosworth D, Duttonm P, Lewis J (eds) Skills Shortages: Causes and Consequences. Ashgate Publishing, Aveubury, pp 10-23

29. Clarke L, Wall C (1998) A Blueprint for Change: Construction Skills Training in Britain. The Policy Press, Bristol, pp 15-18

30. Pueyo F, Sanso M (2005) Technological change, human capital update and growth policies. Span Econ Rev 7:23-41

31. Haskel J, Martin C (2001) "Technology, Wages, and Skill Shortages: evidence from UK Micro Data", Oxford Economic Papers. Oxf Univ Press 53(4):642-658, October

32. Pentland BT (1995) "Information Systems and Organizational Learning: the Social Epistemology of Organizational Knowledge Systems". Account Manag Inf Technol 5(1):1-22 
33. Avgerou C (1995) "Transferability of Information Systems and Organisational Practices", IFIP WG 9.4. Information Technology and Socio-Economic Development: Challenges and Opportunities, Cairo, Egypt, IFIP, January 9-11, pp 5-12

34. Liisa H (2006) "The lack of skills: an obstacle in teamwork". Team Perform Manag 12(1):5-16

35. Owei V, Bada AO, Aniebonam M (2006) "Addressing the information technology skills shortage in developing countries: tapping the pool of disabled users". J Inf Commun Ethics Soc 4(2):77-89

36. European Commission (2001) "European Competitiveness Report 2001", Brussels

37. Sweeney A (2005) "What is the key to combating the IT skills gap?". Dev Learn Organ 19(5):17-19

38. Wu JH, Wang YM (2007) "Measuring ERP success: the key-users Viewpoint of the ERP to produce a viable IS in the organization". J Comput Hum Behav 23:1582-1596

39. Baskerville R, Pawlowski S, McLean E (2000) "Enterprise resource planning and organizational knowledge: Patterns of convergence and divergence. Proceedings of the International Conference on Information Systems, Brisbane, Australia

40. Volkoff O, Elmes MB, Strong DM (2004) Enterprise systems, knowledge transfer and power users. J Strateg Inf Syst 13:279-304

41. Xu Q, Ma Q (2008) Determinants of ERP implementation knowledge transfer. Inf Manag 45(8):528-539

42. Lech P (2011) Knowledge transfer procedures from consultants to users in ERP Implementations. Electron J Knowl Manag 9(4):318-327

43. Lo CH, Tsai CH, Li RK (2005) "A case study of ERP implementation for opto-electronics industry". Int J Comput Internet Manag 13(1):13-30

44. Cowie G (2003) The importance of people skills for project managers. Ind Commer Train 35(6):256-258

45. Simhan R (2003) It's now a matter of 'talking' skills too. Businessline 1

46. Whetten DA, Cameron KS (2002) Developing Management Skills. Prentice-Hall, Englewoods Cliffs, NJ

47. Homer M (2001) Skills and competency management. Ind Commer Train 33(2):59-62

48. Trevor B (1992) "Project Management 2: the skills needed". Manag Account 70(4):20

49. Katz H (1955) Skills of an effective administrator. Harv Bus Rev 33-42

50. Yukl G (2002) Leadership in Organizations, 5th edn. Prentice-Hall, Upper Saddle River

51. Roper KO, Phillips DR (2007) Integrating self-managed work teams into project management. J Facil Manag 5(1):22-36

52. Stevens MJ, Campion MA (1994) The knowledge, skills and ability requirements for teamwork; implications for human resources management. J Manag 20(2):502-528

53. Kezsbom DS (1988) "Leadership and influence: The challenge of Project Management", American Association of Cost Engineers. Transaction of the American Association, pp. I.2.1. - I.2.4

54. Giles L, Campbell M (2003) The productivity and skills challenge. Ind Commer Train 35(3):99-103

55. Goleman D (1998) What makes a leader? Harv Bus Rev 76(6):93-102

56. Robbins CJ, Bradley EH, Spicer M (2001) "Developing leadership in healthcare administration: A competency assessment tool", Journal of Healthcare

57. Moore LL, Rudd RD (2005) "extension leaders'self-evaluation of leadership skill areas". J Agric Educ 46:1

58. Yukl G (2006) Leadership in organizations, 6th edn. PearsonPrentice Hall, Upper Saddle River, NJ

59. Aladwani AM (2001) Change management strategies for successful ERP implementation. Bus Process Manag J 7(3):266-275

60. Grabski SV, Leech SA, Lu B (2001) Risks and controls in the implementation of ERP systems. Kindly check if the updates made in this reference entry is appropriate. The International Journal of Digital Accounting Research 1 (1): 47-68
61. Major DA, Davis DD, Germano LM, Fletcher TD, Sanchez-Hucles J, Mann J (2007) "Managing Human Resources in Information Technology: Best Practices of High-performing Supervisors". Hum Resour Manag J 46(3):411-427

62. Boyle TA, Strong SE (2006) Skill requirements of ERP graduates. J Inf Syst Educ 17(4):403-412

63. Al-Mashari M, Al-Mudimigh A, Zairi M (2003) Enterprise resource planning: a taxonomy of critical factors. Eur J Oper Res 146:352-364

64. Sangster A, Leech SA, Grabski S (2009) ERP implementations and their impact upon management accountants. J Inf Syst Technol Manag 6(2):125-142

65. Chuang ML, Shaw WH (2008) An empirical study of enterprise resource management systems Implementation From ERP to RFID. Bus Process Manag J 14(5):675-693

66. Woo HS (2007) "Critical success factors for implementing ERP: the case of a Chinese electronics manufacturer". J Manuf Technol Manag 18(4):431-442

67. Pan K, Nunes MB, Peng GC (2011) "Risks affecting ERP postimplementation: Insights from a large Chinese manufacturing group”. J Manuf Technol Manag 22(1):107-130

68. Tilvawala K, Myers MD, Andrade AD (2009) "Information literacy in Kenya", The Electronic Journal on Information Systems in Developing Countries. EJISDC 39(1):1-1

69. Themistocleous M, Irani Z, O'keefe R, Paul R (2001) "ERP Problems and Application Integration Issues: An Empirical Survey", In Proceedings of the 34th Hawaii International Conference on System Sciences, pp 9045-9054

70. Peng GC, Nunes JMB (2009) "Surfacing ERP exploitation risks through a risk ontology". Ind Manag DataSyst 109(7):926-942

71. Finney S, Corbett M (2007) "ERP implementation: a compilation and analysis of critical success factors". Bus Process Manag J 13(3):329-347

72. Ramirez DE (2010) “ERP Crisis Management Through Leadership Communication". Int J Manag Inf Syst 14:1

73. El-Sabaa S (2001) The skills and career path of an effective project manager. Int J Proj Manag 19(1):1-7

74. Tadinen H (2005) "Human resources management aspects of Enterprise Resource Planning (ERP) Systems Projects" Master's Thesis in Advanced Financial Information Systems

75. Wahid F, Setyono P (2010) "Dealing with the misfits in an ERP implementation: Experiences from a university context in Indonesia" Seminar Nasional Aplikasi Teknologi Informasi (SNATI 2010) ISSN: 1907-5022 Yogyakarta, 19 Juni 2010 D-13

76. Olson DL, Chae B, Sheu C (2005) "Issues in multinational ERP implementation". Int J Serv Oper Manag 1:1

77. Xue Y, Liang H, Boulton WR, Snyder CA (2005) ERP implementation failures in China: case studies with implications for ERP vendors. Int J Prod Econ 97(2005):279-295

78. Zabjek D, Kovacic A, Stemberger MI (2009) The influence of business process management and some other CSFs on successful ERP implementation. Bus Process Manag J 15(4):588-608

79. Yen DC, Lee S, Koh S (2001) Critical knowledge/skill sets required by industries: an empirical analysis. Ind Manag Data Syst 433-442

80. Bosilj-Vuksic V, Spremic M (2004) "ERP System Implementation and Business Process Change: Case Study of a Pharmaceutical Company" Journal of Computing and Information Technology

81. Stefanou CJ (1999) "Supply chain management (SCM) and organizational key factors for successful implementation of enterprise resource planning (ERP) systems", Proceedings of the Americas Conference on Information Systems (AMCIS), pp. 800

82. Stewart G, Rosemann M (2001) Industry-oriented design of ERPrelated curriculum: an Australian initiative. Bus Process Manag J 7(3):234-242

83. Feeny D, Willcocks L (1998) Core is capabilities for exploring IT. Sloan Manag Rev 39(3):9-21 
84. Zain MY (2008) "Minimizing the problems of enterprise resource planning (ERP) implementation for small to medium cigarette company through framework for applications of systems thinking (FAST)"Media. Informatika 6(1):57-69

85. Juli T (2003) ““'Work smart, not hard!” An Approach to TimeSensitive Project Management", PMI Congress 2003 - Europe, The Hague, The Netherlands

86. Rosario JG (2000) On the leading edge: Critical success factors in ERP implementation projects. Business World, Philippines

87. Khan A (2002) Implementing SAP with an ASAP methodology focus. Writers Club Press, San Jose
88. King W (2005) Ensuring ERP Implementation Success. Inf Syst Manag Summer 83-84

89. Kotter JP (1990) "What do leaders really do?", Harvard Business Review, May-June, pp. 103-11

90. Nazemi E, Tarokh MJ, Djavanshir GR (2012) ERP: a literature survey. Int J Adv Manuf Technol 61:999-1018

91. Ifinedo P (2006) Extending the Gable et al. enterprise systems success measurement model: a Preliminary Study. J Inf Technol Manag (JITM) 17(1):14-33

92. Ngai EWT, Law CCH, Wat FKT (2008) Examining the critical success factors in the adoption of enterprise resource planning. Comput Ind 59(6):548-564 